\title{
A Critical Discourse Analysis of Three Speeches of King Abdullah II
}

\author{
Fawwaz Al-Abed Al-Haq, Nazek Mahmoud Al-Sleibi \\ Yarmouk University, Irbid, Jordan
}

\begin{abstract}
The aim of the present study is to determine the main linguistic strategies that King Abdullah II uses in his speeches. In order to do just this, the researchers selected three speeches to be the data of the study. As for the machinery, a two-level analysis has been attempted in an integrated manner. At the first level, the three speeches were investigated, coaching with the main principles of the Critical Discourse Analysis (CDA), which are the descriptions of the text, discourse-as-discursive practice, and discourse-as-social-practice. At the second level, in order to determine how King Abdullah II frames the core issue in his speeches, four persuasive strategies of political discourse were employed. These strategies are creativity, reference, circumlocution, and intertextuality. As for the findings, the study finds out that King Abdullah uses these strategies competently in terms of employing them to deliver his messages. He uses the creative expressions to show the reality as it is, i.e., the bad image of the current state of affair and the potential good image of the future. Besides, he uses intertextuality in order to convince American audience about his ideas through resorting to an extract from one of the American presidents. In addition, he uses circumlocution to highlight and magnify certain issues. These issues include the Palestinian-Israeli peace process, the American role in this peace process, and the call for international community to work together against the potential dangers. As regards reference, he focuses on the use of the pronouns of the first speaker (we, our, and I) in order to highlight his core issues mentioned above. The study recommends applying the other strategies of political discourse analysis to King Abdullah's speeches such as, parallelism, indirectness, euphemism, disclaimers, etc.. The study concludes that King Abdullah uses his speeches as a means to reflect both the status quo and his vision towards region political issues.
\end{abstract}

Keywords: critical discourse analysis, creativity, discourse-as-social-practice, discourse-as-discursive practice, King Abdullah's speech

\section{Introduction}

\section{Historical Background}

For nearly a decade, King Abdullah II has attempted to convince all policy makers across the world to become more actively involved in mediating between Israelis and Palestinians. He, in fact, makes use of every occasion to emphasize the importance of such mediation through his in-depth speeches. This study aims at

Fawwaz Al-Abed Al-Haq, professor, Ph.D., English Department, Yarmouk University.

Nazek Mahmoud Al-Sleibi, master, English Department, Yarmouk University. 
analysing these speeches to figure out the main ideologies and strategies used by King Abdullah II to achieve his long-standing political goals.

\section{Theoretical Background}

Definition of discourse analysis. Discourse analysis, which has been widely defined as an investigation of language in use and which is fundamentally interested in the extra-sentential levels, is all in all regarded as a recent field of linguistics (Brown \& Yule, 1983). It was introduced into being when linguistics gets developed, and there is a need to interconnect the fields of linguistics with each other. Indeed, discourse analysis, as Horvath (2009) puts forward, is highly deemed as a broad concept with different definitions and different sub-branches which often cross other linguistic fields. As a result, it is by and large pretended that discourse analysis is permanently an inter-disciplinary study which examines all kinds of speeches, shielded with the main advancements of the CDA theory.

More specifically, Van Dijk (2003) assumes that discourse analysis is best depicted in the so-called relationship between the text and context in which that text is introduced or generated. Detailing more in this prominent point of view, he adds that the word "discourse" is grasped as a text within context in which data are subjected to empirical investigation. Besides, Fairclough (1989) defines the discourse as a term referring to the whole process of the social interaction of which a text is just part or segment affected by other super-linguistic components such as the speaker, audience, and occasion. Discourse, as such, is a broad term with many definitions, which "integrates a whole palette of meanings" (Titscher, Meyer, Wodak, \& Vetter, 2000, p. 42), ranging from linguistics, through sociology, philosophy, and other disciplines.

Critical discourse analysis. Critical Discourse Analysis (henceforth: CDA) is first introduced by the significant works of Van Dijk (1993) who maintains that CDA is not merely a unified model, but a joint point of view on doing linguistics, semiotics, or even discourse analysis. Further, it is broadly claimed that the one element of CDA by which it is distinguished from other, even if related, fields of discourse analysis is represented in its "critical" feature.

Fairclough and Wodak (1997), in turn, suggest that what is crucial for critical discourse analysts is the explicit awareness of their role in society. Continuing a tradition that rejects the possibility of a "value-free" science, they argue that science, and especially scholarly discourse, is inherently part of and influenced by social structure, and produced in the social interaction because of which the text is generated.

CDA, therefore, a kind of discourse analytical investigation which basically considers the way the social power abuse, dominance, and inequality are totally incorporated, reproduced, and resisted by, say, the text and talk in certain contexts such as the social and political contexts (Van Dijk, 2000). Moreover, as a reference for its historical significance, it is worth mentioning that some of the basics of CDA might already be available in the critical theory of the Frankfurt School before the Second World War (Agger, 1992; Rasmussen, 1996).

Yet, the current focus of CDA on language and discourse was initiated with the "critical linguistics" that emerged (mostly in the UK and Australia) at the end of the 1970s (Mey, 1985). CDA has also certain counterparts in "critical" developments in different fields of knowledge, including: sociolinguistics, psychology, and the social sciences, of which some already dating back to the early 1970s (Ibanez \& Iniguez, 1997; Singh, 1996; Thomas, 1993; Turkel, 1996; Wodak, 1996). 
What the followers of CDA try to achieve has been stated by Batstone (1995) who claimed that critical discourse analysts attempt to reveal how texts are constructed so that particular perspectives would be expressed delicately and covertly; because they are covert, they are elusive of direct challenge. Generally speaking, CDA attempts to deconstruct covert ideology which is "hidden" in the text.

Consequently, we would state that CDA is a thorough perspective and a salient tool to analyse the political speeches delivered by King Abdullah II. On sticking to its main principles and themes, it is possible to lay down the main strategies employed by King Abdullah II in order to get his audiences, whoever they are, believe in his ideas and diplomatic solutions.

To do so, it is, we guess, imperative to consider the three stages of CDA as determined by Fairclough (1989) to result in a comprehensive understanding of such important speeches representing the king's policy. In fact, these stages are reflected in the "three dimensional method of discourse analysis", introduced by Fairclough (1995), namely:

(1) Description stage, which is related to the formal properties of the text.

(2) Interpretation stage, which is concerned with the relationship between texts and interaction.

(3) Explanation stage, which is concerned with the relationship between interaction and social context.

Accordingly, we might claim that our conceptual basis is adopted from Fairclough's ideas on discourse and power and discourse and hegemony. The researchers attempt to link social practice and linguistic practice, as well as micro and macro analysis of discourse (Fairclough, 1989). Ultimately, this thesis aims at analyzing the possible interrelatedness of textual properties and power relations, which are also underpinned in Fairclough's conceptual work.

Political discourse analysis. Because this study aims at analysing speeches of a political nature, it is a must to introduce some important information about the definition of political discourse analysis and how political speeches and even texts can be analysed, taking into consideration that analysing political texts is dubbed in linguistic literature as political discourse analysis (henceforth: PDA).

As indicated by Van Dijk (1998), PDA focuses on the analysis of "political discourse". He claims that PDA is both about political discourse, and it is also regarded as a critical enterprise. What is important here, is to state that in the spirit of contemporary approaches in CDA; this would mean that critical-political discourse analysis deals especially with the reproduction of political power, power abuse, or domination through political discourse.

According to both Fairclough's (1995) and Van Dijk's (1993), such an analysis deals with the discursive conditions and consequences of social and political inequality that results from such domination. In addition, one of the observations that needs to be made about political discourse is that it is not a genre, but a class of genres defined by a social domain, namely that of politics (Van Dijk, 1998).

Following Van Dijk (1998) scientific discourse, educational discourse, and legal discourse represent the classes of discourse genres of the domains of science, education, and law, respectively. Thus, government deliberations, parliamentary debates, party programs, and speeches by politicians, are among the many genres that belong to the domain of politics.

PDA is much apparent when dealing with the text through the persuasive strategies adopted. These strategies or devices are varied. In fact, this analysis depends on Al-Abed Al-Haq's (2011) study in which he explores the linguistic and communicative strategies employed by political actors in managing various 
interactional phenomena. In other words, through these twelve strategies we can investigate any political text successfully in terms of linguistic clues. In this research, the researchers will highlight five important characteristics which are: creativity, intertextuality, circumlocution, reference, and metaphor.

\section{Statement of the Problem}

After surveying the literature related, the researchers have the courage to pretend that there is no one single research paper conducting the task of figuring out the speeches delivered by King Abdullah II from the main principles of CDA and the persuasive strategies mentioned above so as to determine the persuasive strategies adopted by the King to get his direct or indirect audience believe in his ideas and diplomatic perspective for the issues of the region.

Actually, this paucity of research about this particular issue has sparked Prof. Fawwaz Al-Abed Al-Haq who encouraged me to study this prominent subject. In general, this study's main problem is to analyse the speeches delivered by King Abdullah II in terms of the main concepts of CDA, taking into account that these speeches did not receive much linguistic attention to tackle with into account.

\section{Purpose of the Study}

This study aims at presenting a modest attempt to point out the major mechanisms of persuasion involved in the speeches delivered by King Abdullah II in 2007, 2010, and 2011 on three different occasions. Besides, the study highlights the stylistic techniques employed by the king in his formal speeches. Finally, the research attempts to reveal the main intended ideologies which exist in the speeches under investigation. Therefore, the current work aims at:

(1) Coaching the speeches delivered by the King within the main tenets and principles of CDA and the persuasive strategies in order to lay down how the King wants to get the addressees to believe in his ideas and solutions.

(2) Revealing the main intended or elusive ideologies found in these speeches, showing, of course, the cultural considerations and diplomatic differences.

\section{Questions of the Study}

This study, thus, purports to answer the following questions:

(1) How does King Abdullah II convince his audience to believe in his ideas and peaceful solutions?

(2) What are the intended ideologies enhanced and involved in these speeches?

\section{Significance of the Study}

This study is of paramount importance since it attempts to provide us with a perspective about the persuasive strategies adopted by King Abdullah II to get his audience to believe in his ideas. Besides, this study tries to prove that the best way to determine (and, of course, understand) the speeches is the use of the major principles of CDA and the persuasive strategies by which we would perceive that King Abdullah II is acknowledged with the discoursal mechanisms to get his goals achieved.

\section{Methods and Procedures}

This chapter presents the research methods and procedures the researchers used throughout the current study, including the sample of the study and data analysis. 


\section{Sample of the Study}

King Abdullah II delivers many speeches on different occasions. The sample of the study consists of three speeches. These speeches were delivered in 2007, 2010, and 2011. All of these speeches were delivered on three different occasions.

\section{Data Analysis}

The conceptual basis to analyze and investigate all of these speeches is coached from Fairclough's perspectives in addition to some persuasive strategies of political discourse as stated by Al-Abed Al-Haq (2011) including: creativity, intertextuality, circumlocution, reference, and metaphor.

Through these devices, it is potential to highlight power, discourse, and hegemony which will be our main focus in these speeches. Accordingly, it is likely to link the social practice and the linguistic practice as it shows in these speeches. So, the macro and micro analysis of discourse as put forward by Fairclough (1989) would be the ultimate objective to meet.

The prime analytical tool of the present thesis depicts the three-dimensional method of discourse analysis, as introduced by Fairclough(1992), namely, the language text, whether spoken or written, discourse practice, and the socio-cultural practices. These dimensions would be sought for throughout the thesis in a fashion which hopefully integrates them totally.

\section{Limitations of the Study}

This study has a number of limitations which should be considered. Firstly, the researchers limit themselves to only three speeches delivered. In fact, the researchers left behind many other speeches deserving much attention and academic scrutiny. Besides, the researchers select only five strategies to lay down the main discoursal findings pertaining to the speeches. The researchers do not call on other strategies which do undoubtedly deserve investigation and which can put forward claims with paramount importance about these speeches. Further, the main theme of this thesis is oriented towards linguistic purposes other than the political ones. Hence, this study is never meant to make political claims.

\section{Findings and Discussion}

This section is divided into five parts . Each of the first four parts analyses the three speeches in light with the selected persuasive strategies which are creativity, intertextuality, circumlocution, reference, and metaphor, respectively. These strategies were selected among other ones due to their knock-on impact and effect on explicating the core ideas of the speeches. Indeed; the three-dimensional methods of discourse analysis, as introduced by Fairclough, are highlighted in the course of analysing the five strategies mentioned above.

\section{Creativity and Metaphor}

Although creativity and metaphor are somehow unique strategies which are different from one another, they are oriented towards the same tool, creative words. So that, it is worthy to discuss them altogether in order to shape the findings in a more concise way of representation.

As regards metaphor, linguists state that metaphors involve a semantic mapping from one conceptual domain to another, often using anomalous or deviant language (Crystal, 1994). In employing metaphors, political actors use a word or phrase to establish a comparison between one idea and another. 
Yet, according to this statement by Van Dijk, it seems that creativity is part of any successful political speech. That is because it plays a significant role in shaping the facts; the speaker wants to deliver, in a way that is accessible for direct or indirect audience. Indeed, the king Abdullah's speeches abound with examples of creativity which in turn shape the policy and expectations the king adopts. Consider the following extract: "Some may say, 'Peace is difficult, we can live with the status quo'. But, my friends, violent killings are taking place as part of this status quo. Palestinians and Israelis are not the only victims" (personal communication).

The King highlights the issue that both Palestinians and Israelis are both in danger if peace is not achieved. The image that both of them are victims of not having peace in between is a creative expression, telling that both sides have to seek an intermediate or compromising solution to their conundrum. This expression which gathers both Palestinians and Israelis in the same status is an implied call for both of them to pursue the peace process which was ceased at the time.

This expression shapes King Abdullah's policy to encourage peace talks because both sides are in the same danger. Depicting them as "victims", king Abdullah urges their mutual work and relationship so as to stymie any negative efforts which can make them victims to dangers and terrorism.

This correlation is generally an attempt to link the social practice of both Palestinians and Israelis who live in the same region and have advantages for achieving peace with the linguistic practice highlight in the speech. Such a correlation reflects the one stage of the CDA, representing in the so-called the explanation stage, which is concerned with the relationship between interaction and social context.

In detail, King Abdullah reflects the social context of both Palestinians and Israelis throughout expressing their status quo as victims for not having peace in between. By doing so, he enhances the interaction which has to be undertaken in order to getting them away of being victims. This relationship expresses the explanation stage of political dialogues and speeches.

In addition, King Abdullah articulates the problems facing Jordan and efforts exerted to encounter such problems in a very creative way, making his speeches very pragmatic and tangible. Consider the following examples:

(1) Indeed, Jordan has one of the most dynamic and diversified economies in the region. Today we are fighting our way through the global economic crisis that has hit this region so hard.

Although Jordan has dynamic and diversified economy which makes it a good country to invest in, it suffers from the same financial problems of the remaining countries of the world which have the same economy and resources. Alongside this, people in Jordan do not give up. They strive to deal with these problems efficiently and considerably. King Abdullah depicts these efforts in a very creative way, using the word "fight". This word implicates best the current circumstances Jordan is living.

Using the word "fight" determines the severity of the economic problems facing Jordan. Any listener would understand that the economic problem in Jordan is true and back to the ground. It is not a marginal call for people to gather money for Jordan, but rather it is a reality Jordan lives. Given that Jordan depends much on the foreign aids which decreases hugely for this crises hitting the whole globe and given that there are limited natural resources, which, in turn, gets the effects of such a crisis much devastating for Jordan, there is really fight to live.

King Abdullah uses the progressive aspect of the verb "fight". Such a usage also reflects the social practice of Jordan. In reality, this progressive aspect entails many significant messages to the whole world. 
Firstly, economic crisis is still hitting Jordan. Secondly, governmental efforts are considerable. Thirdly, there are expectations that the impacts of such a crisis will be for long time. Thus, through using this progressive tense, King Abdullah tries to highlight the internal situation and conditions of Jordan to get other countries to appreciate the governmental efforts exerted and if there are any help they can deliver.

Linguistically speaking, this usage of this very word "fighting" with a progressive aspect reflects the "three dimensional method of discourse analysis", as introduced by Fairclough (1997). Firstly, it reflects the description stage, which is related to the formal properties of the text through using the sound aspect of the verb to highlight the efforts exerted and the duration of the economic crisis hitting Jordan.

Secondly, this word also depicted the relationship between texts and interaction. The text here tells the interlocutors how they must interact with the text through forcing them to understand certain messages the speaker delivers. The semantic content of the word "fight" forces interlocutors to think of Jordan's conditions, throughout accentuating that people here fight for their life. This relationship between texts and interaction is depicted in the second stage which is Interpretation stage.

Thirdly, this word per seemphasizes the social context people in Jordan live. Since there are limited natural resources and a decrease in international aids, the people are really fighting for their life. This understanding reflects the explanation stage, which is concerned with the relationship between interaction and social context. Table 1 shows other expressions stressing both creativity and metaphor in the three speeches.

Table 1

The Expressions Stressing Both Creativity and Metaphor in the Three Speeches

\begin{tabular}{|c|c|c|}
\hline NO. & The expression Word(s) of creativity & The speech \\
\hline 1. & a place where individuality is nurtured... & Nurtured 1 \\
\hline 2. & Thousands of people have paid the highest price & Paid the highest price 1 \\
\hline 3. & the cycle of crises is spinning faster... & Cycle 1 \\
\hline 4. & violent crisis is the enemy of all global prosperity and progress.... & Enemy 1 \\
\hline 5. & The little girl, born in Iraq, with her wide eyes full of wonder, let her have a life of peace..... & Wide eyes 1 \\
\hline 6. & No-where are the opportunities more powerful-more enduring - more ripe — than in Jordan... & More ripe 2 \\
\hline 7. & This year's short-term dislocations should not take our eyes off the prize:... & Our eyes 2 \\
\hline 8. & my country will do what it takes to create growth for you and for us... & To create growth 2 \\
\hline 9. & open the doors of enterprise and opportunity... & open the doors 2 \\
\hline 10. & $\begin{array}{l}\text { Civil-society leaders from many different sectors are working together in a dialogue on our } \\
\text { future... }\end{array}$ & A dialogue on our future 2 \\
\hline 11. & $\begin{array}{l}\text { That would also be an essential step toward neutralising forces of evil and war that threaten all } \\
\text { peoples... }\end{array}$ & Forces of evil and war 3 \\
\hline 12. & All eyes are upon us... & All eyes are upon 3 \\
\hline 13. & the price of failure will be too high for all... & The price of failure 3 \\
\hline
\end{tabular}

As indicated in Table 1 above, we can state that drawing creative expressions is a very commonplace strategy in King Abdullah's speeches. In fact, he uses these expressions to highlight the idea he wants to deliver. For instance, the metaphorical image in the expression "the price of failure will be too high for all" is very significant and expressive.

As one knows that failure is never counted by prices or money, yet the King makes failure as a commodity which all of us, the audience, will pay against its price. That means failure has negative and comprehensive effects on all of the interlocutors. In conclusion, this mere image has creative standpoint to encourage all 
interlocutors to work altogether and has metaphorical standpoint in depicting the failure as a price.

Further, it seems that King Abdullah uses creative images to reflect the actual state of affair. It means that the state of affair is sometimes (or often) a little bit complicated. Consequently, the speaker is forced to use figures of speech to maintain the exact conditions or as Fairclough calls "the social practice". Such a theory is clearly represented in two creative expressions listed in Table 1 above. These two expressions are as follows:

(2) A. "Violent crisis is the enemy of all global prosperity and progress..."

B. "And that would also be an essential step toward neutralising forces of evil and war that threaten all peoples..."

As regards the first extract, it seems that King Abdullah reflects the current conditions the people worldwide live in a very outstanding way. He envisions the violent crisis which hits all of world countries as an "enemy of all global prosperity". He wants to say that this global crisis has very devastating effects on Jordan which shares other countries with the impacts of this crisis. In reality, this sharing is the real social practice Jordan lives in.

Concerning the second extract, the king Abdullah emphasises the idea of existing the forces of evil and war. This creative image entails that evil and war need international collaboration because they have forces. Depicting evil as having forces as an exaggerating metaphorical image to encourage politicians to work alongside each other so as to encounter these forces and eliminate every potential chance for.

These two images obviously highlight the interpretation stage of CDA as put forward by Fairclough. In detail, these images, for example, pave us the road how we can grasp the speech and pick up the messages the speaker wants to deliver. So that it is merely a relationship between the speech and interlocutors' interaction with.

In addition, these two creative expressions, I believe, oblige the interlocutors to interact in a specific way. It is not their choice to opt what interactions they want or understand, rather they are apparently enforced to seek for the meanings and ideas the king wants to deliver.

Accordingly, King Abdullah uses creative expressions with highly metaphorical forces in order to guide the interlocutors towards the meanings he wants to deliver. This guidance is called, according to Fairclough's concepts, as the explanation stage, which is concerned with the relationship between interaction of the interlocutors and the social context these creative expressions are made in.

What is important and significant here to tell as a last point is the issue of the type of the creative images King Abdullah draws. That is to say, the type of these creative expressions is according to whether these expressions are positive or negative. Upon surveying all creative expressions found in the three speeches of the study data, one would hypothesize that King Abdullah balances between the creative expressions in terms of repetition. He mentions the creative expression entailing the positive point of view in a balance with those which entail the negative point of view. This is clearly shown in Table 2 below.

Table 2

The Type of the Creative Expressions Used in the Speeches in Terms of Positivity or Negativity of the Image

\begin{tabular}{lll}
\hline NO. & The expression & The type \\
\hline 1. & a place where individuality is nurtured... & Positive \\
2. & Thousands of people have paid the highest price, & Negative \\
3. & the cycle of crises is spinning faster..... & Negative
\end{tabular}


4. violent crisis is the enemy of all global prosperity and progress....

5. The little girl, born in Iraq, with her wide eyes full of wonder, let her have a life of peace.....

6. No-where are the opportunities more powerful - more enduring - more ripe - than in Jordan....

Positive

7. This year's short-term dislocations should not take our eyes off the prize:...

Positive

my country will do what it takes to create growth for you and for us......

Positive

9. open the doors of enterprise and opportunity...

Positive

10. Civil-society leaders from many different sectors are working together in a dialogue on our future..

Positive

11. That would also be an essential step toward neutralising forces of evil and war that threaten all peoples...

Negative

All eyes are upon us...

Negative

13. the price of failure will be too high for all...

Negative

As shown in Table 2 above, King Abdullah uses both negative and positive expressions in his speeches. Linguistically speaking, this usage is not haphazard, but rather intentional, and, at the same time, it reflects the status quo or the so-called social context as introduced by Fairclough. In detail, King Abdullah uses the positive creative expressions to reflect the future expectations, whereas he uses the negative creative expressions to reflect the current status quo.

In fact, this depiction of the two kinds of the creative expressions reflects the social context. These speeches were delivered in an unstable status of political situation. The appreciation of the current conditions is unfortunately negative. Yet, the expectations for future are for posterity and global collaboration, thus, the expressions were positive.

This configuration entails King Abdullah's point of view and his understanding of the events of the world. He has outstanding skills to understand the status quo, and, at the same time, his future outlook is positive for all events. This diversity reflects his majesty's policy in dealing with political issues.

He deals with the political issues according to the state of affair but tires his best to get this state of affair for such political issue positive in the future. Besides, this diversity stands for the social context which is, here, divided into two categories, i.e., negative current conditions and potential positive future conditions.

\section{Intertextuality}

Intertextuality is one of the important political communicative strategies. It involves borrowing from pervious texts or text-types in creating a new one. Actually, intertextuality is a very persuasive strategy to get the listeners consider what the speaker says. That is because you would market your idea according to others' speeches or written works. It becomes as super-evidence for what you call for (Waaijman, 2010).

So, we can maintain that intertextuality is a tool of interaction between the interlocutors of, say, a speech. This effect is by and large depicted in King Abdullah's speeches. He uses this strategy when the need arises or when he markets his idea which is completely or partially compatible with the listeners' ones.

King Abdullah's use of intertextuality can be recognized as a timely and purposeful use. This claim would be validated through the following direct borrowing used by King Abdullah in his first speech calling the American Congress, the supreme legislative power in the strongest country in the world, the United States of America.

(3) "A decent respect for the rights and dignity of all nations, large and small" (personal communication). That's how President Roosevelt - the great F.D.R.—-described the basis of American foreign policy.

The prudent reader of such a text will determine that King Abdullah attempts to encourage the United States 
of America for more effective role in the Middle East Peace process. That is meant to state that the United States of America can take a more vital part in encouraging (or even) forcing all sides involved in the Middle East Peace process. This encouragement entails that the American role is still not enough towards such a process.

Highlighting the American role is a must from a pragmatically political point of view since the United States of America is able to enforce Israel to be more serious in the Peace process along side with Palestinians. To encourage the United States of America for further role, King Abdullah uses intertextuality to convince them to do so.

$\mathrm{He}$ borrows an extract from one of the most beloved American presidents for Americans, President Roosevelt, whose sayings are mush respected and considered not only by the American politicians but also by the American people.

The King reminds the American congress, the decision maker of the American policy, about the basis of the American foreign policy for which the United States of America became involved in. This basis is not introduced by the king but by the American people themselves. This basis is the decent respect for the rights and dignity of all nations, large and small. Depending on the place of this saying in King Abdullah's speech, we can tell that he brings this saying in order to emphasize the idea of more American role in the Middle East Pease process.

Analysing the whole speech in which this extract comes into being, one can state that it is the most appropriate time and place. In detail, mentioning Roosevelt's sentence becomes after four sentences which form the main idea of all of the speech. These sentences are:

(4) A. Some may say, "Peace is difficult, we can live with the status quo".

B. Some may say, "But there are other, urgent challenges".

C. There are those who say, "It's not our business".

D. Some will say: "This is not the core issue in the Middle East". (personal communication)

Consequently, we would claim that King Abdullah attempts to answer all possible questions which can be posed because of his urgent call for the United States of America for more effective role in the Middle East Pease process between Palestinians and Israelis. He underlines that peace is not difficult as some may think. In addition, he explains that Middle East Pease process is a real and urgent challenge because it does not only affect Palestinians and Israelis.

Roughly speaking, King Abdullah resorts to intertextuality as a tool for persuasion when the need arises. Using intertextuality in such a harmony way obliges the interlocutors to adopt his point of view. Again, this professional use of Intertextuality reflects the interpretation stage of CDA through getting the American congress absorb the message the king wants to deliver, which is here, the United States of America has to more involved in the peace process, and he introduces them hard evidence for such involvement.

\section{Circumlocution}

Through circumlocution politicians are able to avoid the obvious and save face (Obeng, 1997). These politicians are also able to make (ir) relevant additions and thus to elaborate in detail their own group's beneficial action and horror stories about their enemies (Van Dijk, 2000). On the contrary, politicians may resort to selection, mentioning only information hurtful to them for partisan reasons. Hyperbole or exaggeration is an effective discourse tool employed when the politicians are engaged in circumlocution. 
Depending on the study sample, we would in general claim that King Abdullah uses circumlocution as a tool to convince the audience about his messages. What holds important for us is to examine how he uses this and links the findings with the CDA stages mentioned above in order to establish a strong floor for our findings.

As maintained in the speeches, we would hypothesize that King Abdullah has central issue to focus upon. To put it differently, although every speech has a unique occasion and different place in comparison with other speeches, King Abdullah accentuates certain issues which form the core of all of his speeches. These core issues are as follows:

(1) The Palestinian-Israeli peace process;

(2) The American role in this peace process;

(3) The call for working together against the potential dangers;

(4) Jordan's commitment towards the issue of the region.

This highly frequent mention is, of course a kind of Hyperbole or exaggeration which is held to be of the tools of circumlocution. The highly repetitive words entail the prime the core ideas of the king's speeches of the study sample. Table 3 shows the most frequent words in the three speeches with how many times they were mentioned. Also, the table below shows the part of the speech each word is.

Table 3

The Highly Frequent Words in the Three Speeches

\begin{tabular}{llll}
\hline NO. & Word & Parts of Speech & How many times \\
\hline 1 & Must & Verb & 22 \\
2 & America & Noun & 20 \\
3 & Palestinian & Noun & 14 \\
4 & Middle east & Noun & 13 \\
5 & Israeli & Noun & 12 \\
6 & Commitment & Noun & 7 \\
7 & Should & Verb & 5 \\
\hline
\end{tabular}

As shown in Table 3, the most highly frequent word in the all of the speeches in the word "must" with 22 mentions, followed by the word "America" with 20 mentions, followed by the word "Palestinians" with 14 mentions, followed by the word "middle east" with 13 mentions, followed by the word "Israel" with 12 mentions, followed by the word "commitment" with seven mentions. The least highly frequent word is the world "should" with only five mentions.

Since "must" is the most frequent word in the speeches, it is our debate here. In detail, King Abdullah uses the word "must" much in all of his speeches. This use is very significant especially when we know that this word accompanies certain words which provide us the clues about the social context which is regarded as the backbone of the three stages of the CDA, represented by Fairclough. Table 4 shows the words accompanying "must" in all of the speeches.

Based on Table 4, it is clear the word "must" accompanies, as a subject to, four important words which totally represent the core issues of these issues. These words are "I", "Peace", "America", and "we". 
Table 4

The Words Accompanying "Must" in the Three Speeches

\begin{tabular}{llll}
\hline NO. & The subject & Verb & Object \\
\hline 1 & I & must & Speak \\
2 & I & must & Speak \\
3 & I & must & Speak \\
4 & I & must & Speak \\
5 & America & must & Play the central role \\
6 & I & must & Speak \\
7 & We & must & Take risk for peace \\
8 & The goal & must & Be a peace \\
9 & It (peace) & must & Be anchored in security \\
10 & It & must & be a peace \\
11 & It & must & be a peace \\
12 & It & must & be a peace \\
13 & The united states & must & Be engaged \\
14 & We & must & Make our progress \\
15 & We & must & Achieve an agreed solution \\
16 & The justice of morality & must & Win \\
17 & We & must & Leave it to another generation \\
18 & We & must & Work together \\
19 & We & must & Work together \\
20 & We & must & Speak \\
21 & We & must & Prevail \\
22 & Tomorrow & must & Show result \\
23 & We & Mustn't & Spare no effort \\
24 & They (interlocutors) & Must & Interact with text \\
25 & America's role & is & A must \\
\hline & & &
\end{tabular}

The expression "I must speak" occurs five times in the speeches especially in the first speech which was delivered before the American congress. This expression is of paramount importance because it entails the main purposes of such a speech. King Abdullah believes in that America must play further roles in order to achieve the peace between both the Palestinians and Israelis. As a result, this obligation towards such an important issue is a must.

The expression "we must work together" also occurs much especially in the local speeches which stands for the current condition in Jordan and the in the Middle East. The call of working together is best rendered in such expressions which are linguistically amplified by using a strong work such as "must".

Therefore, what is important to tell here is that King Abdullah wants to say that the United States of America must be involved more in the peace process, but this is only not enough for comprehensive peace, we must work alongside each other to get the peace prevail. To put it differently, peace process in the Middle East needs international unanimity.

Although the word "should" refer to some kind of obligation and a serious call for further actions, but it does not totally stand for the bad situation of the Middle East peace process. So, the best word to use is "must" not "should". In addition, this underlying usage expresses also the interpretation stage of CDA in that the audience has to grasp the king Abdullah's message as he wants. 
To sum up, using the word "must" and "should" in such a way tells us a very significant fact about these speeches. This fact is represented in that that King Abdullah tries to control both his messages and his audience' appreciation to these messages, more or less.

\section{Reference}

Political pronouns are used to signal roles (such as agency) and for self-reference and identity (Van Dijk, 2000). For example, the opposition between "us" and "them" may signal polarization of in-groups and out-groups.

What is important here to tell is that King Abdullah II uses the pronouns in a very meticulous technique so as to underlie the core issues he wants to deliver. King Abdullah II focuses in his speeches on the first and second person pronouns more than the third person pronouns, indeed. Such a focus creates a state of affair of balance between the speaker and the hearers in order to get these speeches accessible and direct to the point. This balance helps King Abdullah II to get the audience more involved in his underlying ideas.

This usage is of paramount importance since it discovers the main issue of these speeches, to be active not passive, which, in turn, reflects completely one of the principles of CDA which is, discourse-as-social-practice. This use tells how the discourse is a social practice more than a merely linguistic one.

Table 5 shows the subject pronouns used in these speeches with emphasis on the first and second person pronouns, the most common pronouns mentioned in the speeches.

Table 5

Subject Pronouns Used in the Study Data

\begin{tabular}{lll}
\hline NO. & Pronoun & Number of frequency \\
\hline 1 & We & 55 \\
2 & I & 24 \\
3 & You & 18 \\
\hline
\end{tabular}

As shown in the table above, it is very clear that the pronoun "we" is the most frequently used pronoun in all of the speeches with 55 mentions. This frequency is very significant because, as mentioned above, it establishes the mutual correlation between the speaker and hearer to work alongside with each other.

Besides, using this pronoun builds up a state of intimacy between the interlocutors. This state is essential to build up a common floor for further understanding and working together. All of these implications, in fact, reflect the social practice and pragmatic implications of using such a pronoun.

The second most used pronoun is "I", followed by "you" with 24, and 18 mentions, respectively. It seems that King Abdullah II depends more on the personal level to establish common understanding in between, but with no negligence of other's part and role in such establishment. In other words, we would claim that King Abdullah II is a self-driven leader in political actions which are highly represented in his local and international initiatives such as Amman Message.

However, this focus on these kinds of pronouns can be verified by surfing the genitive-case pronouns of the pronouns mentioned in Table 5. Table 6 shows the genitive pronouns used in the speeches. 
Table 6

Genitive Case Pronouns Used in the Speeches

\begin{tabular}{lll}
\hline NO. & Pronoun & Number of frequency \\
\hline 1 & Our & 42 \\
2 & Your & 16 \\
3 & My & 16 \\
\hline
\end{tabular}

As shown in Table 6, the same findings can be drawn. In detail, King Abdullah II uses the pronoun "our" in order to establish the mutual correlation between him and the hearers to work alongside with each other and to build up a state of intimacy in between.

Yet, King Abdullah II does not use the objective pronouns much in his speeches in order to be away from the idea of being passive in, say, the peace process of the middle east. He strives to get his audience hold an active role for the different issues alluded in the speeches. Table 7 shows the low use of such pronouns as compared with the subject or genitive pronouns with an emphasis on the first person pronouns.

Table 7

Objective Pronouns Used in the Speeches

\begin{tabular}{lll}
\hline NO. & Pronoun & Number of frequency \\
\hline 1 & Us & 9 \\
2 & $\mathrm{Me}$ & 4 \\
\hline
\end{tabular}

\section{Concluding Remarks}

The present study has answered its two questions. The first question is: "How does King Abdullah II convince his audience believe in his ideas and peaceful solutions?" The findings of the study show that there are different strategies King uses to deliver his messages and get his audience believe in them. These strategies include creativity, reference, intertextuality, metaphor, and circumlocution. The second question is: "What are the intended ideologies enhanced and involved in these speeches?" The findings indicate that according to the CDA principles and the strategies used, King Abdullah II focuses on four core issues which represent the main ideology involved in the speeches which is "the mutual correlation between the different parties".

\section{Conclusion and Recommendations}

\section{Conclusion}

The current study comes up with the following conclusions:

(1) Drawing creative expressions is a very commonplace strategy in King Abdullah's speeches. In fact, he uses these expressions to highlight the idea he wants to deliver.

(2) Upon surveying all creative expressions found in the three speeches of the study data, one would hypothesize that King Abdullah balances between the creative expressions in terms of repetition. He mentions the creative expression entailing the positive point of view in a balance with those which entail the negative point of view.

(3) King Abdullah resorts to intertextuality as a tool for persuasion when the need arises. Using intertextuality obliges the interlocutors to adopt his point of view. 
(4) These core issues of the speeches are "the Palestinian-Israeli peace process", "the American role in this peace process", "the call for working together against the potential dangers", and "Jordan commitment towards the issue of the region".

(5) "Must" is the most frequent word in the speeches; the King uses this word much in all of his speeches. This use is very significant especially because it accompanies certain words which frame the main messages intended and ideologies involved. These words are "I", "Peace", "America", and "we".

(6) King Abdullah's policy and opinions are moulded in the speeches through the uses of referential pronouns. He focuses on the first and second person pronouns. This use establishes a mutual correlation between him and hearers so as to work alongside with one another. Besides, using such pronouns helps to set up a state of intimacy between the interlocutors. This state is essential to build up a common floor for further understanding and working together.

(7) The King depends also on the subjective pronouns to get all interlocutors active not passive, which reflects the social practice of these speeches.

\section{Recommendations}

Having studied the speeches delivered by King Abdullah II, the researchers recommend the following for further research:

(1) Reinvestigating other speeches of King Abdullah II, coaching with the Critical Discourse Analysis themes. Many studies dealing with such speeches emphasize their layouts and political underlying roles without determining the linguistic clue enabling him persuade other political leaders to adopt his opinions and political solutions.

(2) Reinvestigating other kinds of texts and speeches in the Arabic Languages, shielded with the Critical Discourse Analysis and Political Discourse Analysis.

(3) Conducting a study indicating whether King Abdullah II follows the same strategies in all kinds of his speeches, i.e., national, social, etc. speeches.

(4) Applying the other political discourse strategies such as evasion, euphemism, and rhetoric on King Abdullah's speeches.

\section{References}

Abdulwahid, Y. (2011). Metaphors and their morality implications in political speeches: A pragmatic study. Faculty of Education Journal, 2(4).

Agger, B. (1992). The discourse of domination: From the Frankfurt school to postmodernism. Evanston, IL: Northwestern University Press.

Al-Abed Al-Haq, H. (2011). Persuasive strategies in political discourse. The first international forum on media and information. The PS in political mass communication media, Sid Mohamed Ben Abdullah Uni., Fez, Morocco.

Al-Abed Al-Haq, F., \& Hussein, A. (2011). The slogans of the Tunisian and Egyptian revolutions: A sociolinguistic study. Issues in Political Discourse Analysis, 4(1), 39-58. New York: Nova science Publishers.

Al-Qur'an, A. (2013). An analytical study of prophet Mohammad's letters to Kings: From a discourse analysis perspective (Unpublished Master thesis, Yarmouk University, Irbid, Jordan).

Al-Saideen, D. (2011). The political discourse of King Abdullah II Ibn Al-Hussein and its impact on reform and modernization in Jordan (1999-2005) (Unpublished Master thesis, AalAlbayet University, Al-Mafraq, Jordan).

Atawneh, A. M. (2009). The discourse of war in the Middle East: Analysis of media reporting. Journal of Pragmatics, 41, $263-278$. Batstone, R. (1995). Grammar in discourse: Attitude and deniability. In G. Cook \& B. Seidlhofer (Eds.), Principle \& practice in 
applied linguistics (pp. 197-213). Oxford: Oxford University Press.

Brown, G., \& Yule, G. (1983). Discourse analysis. Cambridge: Cambridge University Press.

Cap, P. (2008). Towards the proximization model of the analysis of legitimization in political discourse. Journal of Pragmatics, 40, $17-41$.

Crystal, D. (1994). An encyclopedic dictionary of language and languages. Oxford: Blackwell.

Dedaic, M. (2005). Ironic denial: Toboze in Croatian political discourse. Journal of Pragmatics, 37, 667-683.

Fairclough, N. (1989). Language and power. London: Longman.

Fairclough, N. (1992). Discourse and social change. London: Polity Press.

Fairclough, N. (1995). Critical discourse analysis: The critical study of language. Harlow, UK: Longman.

Fairclough, N. L., \& Wodak, R. (1997). Critical discourse analysis. In T. A. Van Dijk (Ed.), Discourse studies a multidisciplinary Introduction (Vol. 2). Discourse as social interaction (pp. 258-84). London: Sage.

Fløttum, K. (2009). EU discourse: Polyphony and unclearness. Journal of Pragmatics, 42, 990-999.

Gadalla, H. (2011). Rhetorical strategies in Barack Obama's Cairo speech: A critical discourse analysis. Issues in political discourse analysis, 4(1), 73-91. NewYork: Nova Publishers.

Halliday, M. A. K., \& Hasan, R. (1976). Cohesion in English. London: Longman.

Horvath, J. (2009). Critical discourse analysis of Obama's political discourse. In M. Ferencik \& J. Horvath (Eds.), International conference proceedings of Language, literature and culture in a changing transatlantic world (pp. 45-56). Presov: University of Presov.

Ibanez, T., \& Iniguez, L. (Eds.). (1997). Critical social psychology. London: Sage.

Janks, H. (2002). Critical discourse analysis as a research tool. In M. Toolan (Ed.), Critical discourse analysis (Vol. 4, pp. 26-42). London: Routledge.

Mey, J. L. (1985). Whose language: A study in linguistic pragmatics. Amsterdam: Benjamins.

Morley, J. (2004). Power and ideology in everyday discourse: The relevance of critical discourse analysis in pragmatic linguistics [PDF document]. Retrieved from http://library.sakura.juntendo.ac.jp/bunken/kiyou/vol8/20.pdf

Nuolija R., \& Tiittula, A. (2011). Irony in political television debates. Journal of Pragmatics, 43, 572-587.

O'Halloran, K. (2005). Causal cognition and socio-cognition in critical discourse analysis: A reply to Rick Iedema. Linguistics and Education, 16, 338-348.

Obeng, S. G. (1997). Language and politics: Indirectness in political discourse. Discourse and Society, 8(1), 49-83.

Proctor, K., \& I-Wen, L. (2011). The 1st person plural in political discourse-American politicians in interviews and in a debate. Journal of Pragmatics, 43, 3251-3266.

Rasmussen, D. M. (Ed.). (1996). The handbook of critical theory. Oxford:Blackwell.

Singh, R. (Ed.). (1996). Towards a critical sociolinguistics. Amsterdam: Benjamins.

Taiwo, R. (1997). Language, ideology and power relations in Nigerian newspaper headlines: Nebula. Retrieved from $\mathrm{http} / /$ www.google.co.uk/url?sa=t\&rct=j\&q=\&esrc=s\&frm=1\&source=web\&cd=1\&ved=0CC0QFjAA\&url=http $\% 3 \mathrm{~A} \% 2 \mathrm{~F} \%$ 2Fwww.nobleworld.biz\%2Fimages\%2FTaiwo2.pdf\&ei=eQBcUrOrDseY0QXH34HQBw\&usg=AFQjCNFUxHFgXSaf_0W Ptb_lhkt7YEtKUw

Thomas, J. (1993). Doing critical ethnography. Newbury Park: Sage.

Titscher, S., Meyer, M., Wodak, R., \& Vetter, E. (2000). Methods of text and discourse analysis. London: Sage.

Turkel, G. (1996). Law and society: Critical approaches. Boston, MA: Allyn and Bacon.

Van Dijk, T. A. (1993). Principles of critical discourse analysis. Discourse and society, 4(2), 249-283.

Van Dijk, T. A. (1998). Towards a theory of context and experience models in discourse processing. In H. Van Oostendorp \& S. Goldman (Eds), The construction of mental models during reading. Hillsdale, NJ: Erlbaum.

Van Dijk, T. A. (2000). Parliamentary debates. In R. Dins Wodak \& T. A. Van Dijk (Eds.), Racism at the top: Parliamentary discourses on ethnic ISsues in six European states (pp. 45-78). Klagenfurt, Austria: Drava Verlag.

Van Dijk, T. A. (2003). Critical Discourse Analysis. In D. Schiffrin, D. Tannen, \& H. E. Hamilton (Eds.), The handbook of discourse analysis (pp. 352-371). Oxford: Blackwell.

Waaijman, K. (2010). Intertextuality: On the use of the Bible in mystical texts. Hervormde Teologiese Studies, 66, 1-7.

Wodak, R. (1996). Disorders of discourse. London: Longman. 